current and the giving rest to the diseased portion of the bowel. In intestino-vaginal fistula following hysterectomy a bilateral exclusion is performed and the sequestrated loop drains into the vagina. The discharge soon lessens and within a few weeks becomes almost imperceptible. In cases of cholecystenterostomy; the gall-bladder is joined to the portion of bowel cut off by unilateral exclusion. In chronic invagination; the operation has been performed on three occasions. In cases of artificial anus and fæcal fistula; in these conditions other operations are always to be preferred. In cases of colitis an entero-anastomosis or a unilateral exclusion, the ileum being joined to the sigmoid flexure, has been performed with marked relief to the inflamed and perhaps ulcerated bowel. In chronic intractable constipation unilateral exclusion has been performed; the ileum has been divided about one foot above the ileo-creal valve and the proximal end implanted into the sigmoid flexure or the upper end of the rectum.

The operation of exclusion of the intestine is chiefly necessary in cases of chronic inflammatory disease, probably tuberculous, involving the bowel and leading to external fistula; in cases of inoperable carcinoma of any part of the large intestine, especially of the cæcum and ascending colon; and in rebellious cases of muco-membranous colitis. From what has been said it will be recognised that unilateral exclusion, save in cases of disease affecting the lower end of the ileum, offers no advantages over lateral anastomosis, and that bilateral exclusion affords the best means of dealing with certain diseases, chiefly tuberculous and malignant, in the cæcum and colon, and with fistulæ between the small intestine and the bladder or vagina.

For the drawings which illustrate this paper I am indebted to Miss Ethel Wright. Leeds.

\section{SIX CASES OF SPLENIC ANÆMIA IN ONE FAMILY.}

BI J. W. SPRINGTHORPE, M.A., M.D. MELB. M.R.C.P. LOND.,

PHYETCIAT TO THE MELBOURNE HOSPITAL; LECTURER TO THE UNIVERSITY OF MELBOURNE.

With Remarks on Two Cases in which Splenectomy was performed, by R. A. STIRLING, M.D. Melb., Surrgeon to the Melbourne Hospital.

MODERN medicine is increasingly concerning itself with conditions of the blood. We find bound up therein the great questions of heredity, vulnerability, and immunity. We use the blood for serum diagnosis and treatment; we make from it leucocyte counts before operations; we think of it as fed from the gastro-intestine, perfected by internal secretions, purified by the excretory organs, and undergoing in the capillaries all the anabolic and katabolic metabolisms that accompany functional activity, growth, and decay. We find in it also germs, protozoa, filaria, we recognise its response to attack in defensive proteids and antitoxins, and in some cases we even imitate this specific adjustability. Gradually, too, we are coming to understand the significance of its different parts, its alkalinity, its oxidations, and its coagulation. Already we have reason to believe that the erythrocytes are the carriers of oxygen and proteid; that normoblasts make for blood regeneration and microblasts and megaloblasts for blood degeneration; that the polynuclear cells are phagocytes; that the myelocytes are marrow cells and the lymphocytes the products of the adenoid tissues, though we can still only guess at the functions of the eosinophiles, basophiles, mast cells, and blood plaques. We are thus clinically interested in leucocytosis, lymphocytosis, leucopenia, eosinophilia, oligocythæmia, polycythæmia, polychromatophilia, and the great divisions of anæmia, primary and secondary.

Of all forms of anæmia, those connected with splenic enlargement are amongst the most interesting. 'The function of the spleen is still an unsettled matter. According to Wolff it contains indifferent cells, which normally produce non-granular leucocytes, though if the function of the bone marrow be upset then it can produce granular leucocytes and even erythrocytes. Clinically, we find an enlarged spleen present in leukæmia and Hodgkin's disease and in anæmias due to gastro-intestinal infection, rickets, syphilis, malaria, hepatic cirrhosis, malignant amyloid and hydatid disease. But there are special forms of obscure origin, known as splenic anæmia, found in infants as well as in adults. (a) The splenic anæmia of infants is well described by Hutchison in the late Goulstonian lectures. The patient is usually from six to 24 months old and mildly rickety. The liver is enlarged as well as the spleen; there is no great tendency to hæmorrhage; the blood picture is that of a severe anæmia, with a marked polymorphism, some leucocytosis, some myelocytes, and a marked increase in mast cells. The cases are of short duration, recovery is frequent, and death, if it occur, is due generally to bronchopneumonia. The pathology is not peculiar-simply a chronic splenitis, affecting chiefly the pulp. Hutchison considers the cause not rickets or syphilis but toxic infection from the intestinal flora. (b) Quite different is the splenic anæmia of adults (though Hutchison considers that this variety also occurs at times in children after second dentition-i.e., when the blood has assumed adult characters). The anæmia is profound and attended with hæmorrhages, gastro-intestinal disturbances, icterus, and pyrexial attacks. The splenic enlargement is uniform, very marked, and painful. The blood picture is a leucopenia, with an anæmia of the pernicious type in advanced cases, and relative lymphocytosis (a full diagnostic table will be found in Da Costa's “ Hrmatology," p. 234).

In leukæmia, on the contrary, there are leucocytosis and the myelocytic type of blood; and in Hodgkin's disease, though the blood picture may be identical, the spleen is much smaller and the lymphatic glands are enlarged. In syphilis there are, in addition to the recognised clinical signs, an even more marked oligocythæmia, a very low colour index, and a noticeable leucocytosis of the lymphocyte type. The series which I am now recording is apparently unique. It contains three sisters and one brother, with his son and niece. The family tree is appended. It bas been impossible, so far, to determine whether the other two brothers and ten cousins are or are not affected :-

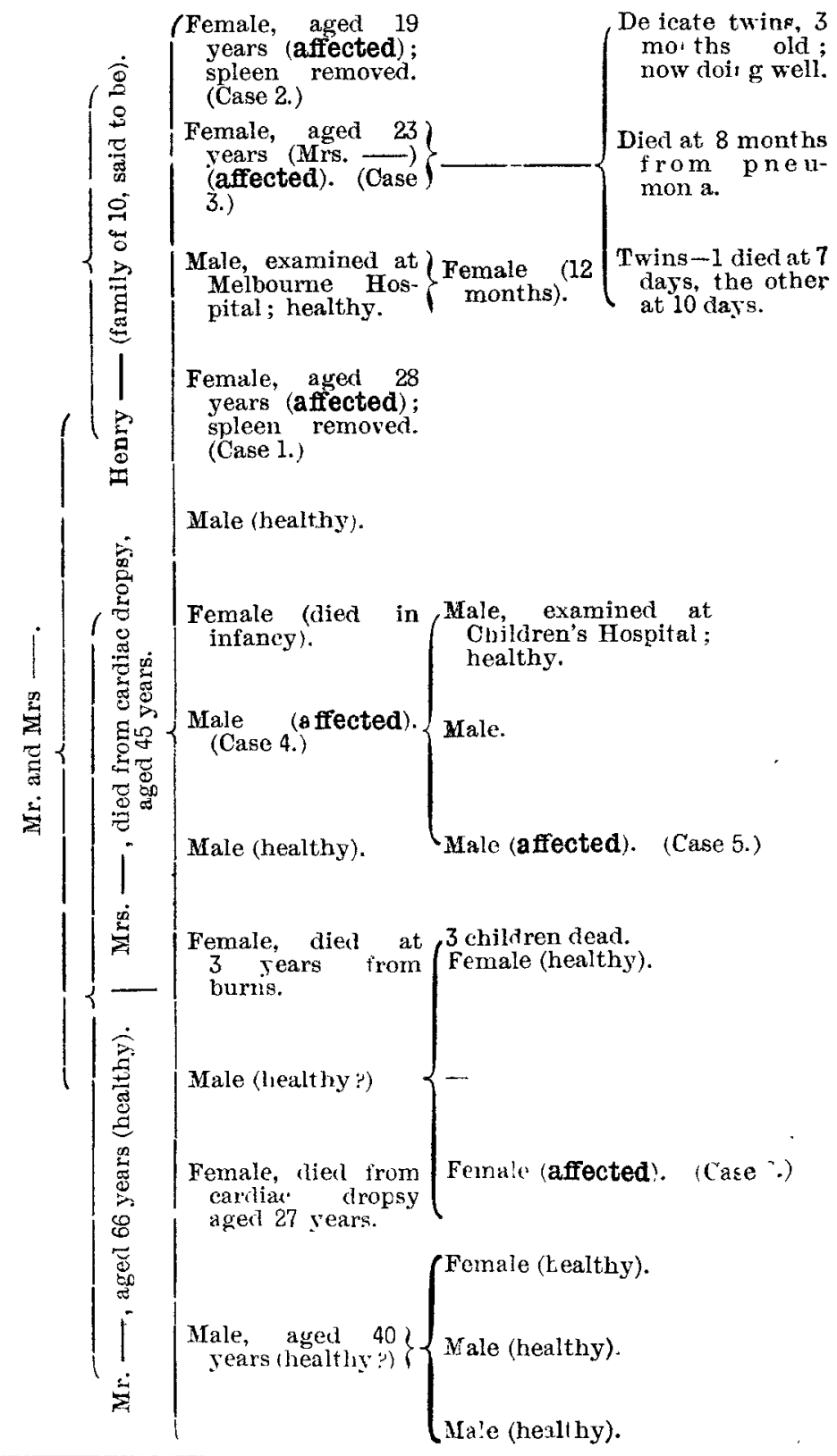

1 Tre Laveret. May 14th, 1904, p. 1223. 
There is no family history of congenital syphilis or of syphilis having been acquired in any of the cases, except perhaps one. All the family were born at Portarlington, came to South Melbourne in 1885, and have ever since lived there or in Brunswick.

CASE 1.-Whis patient, who was a female aged 28 years, first came under notice in May, 1903. She had typhoid fever in 1884 at eight years, measles slightly at 13 years, and bilious attacks with vertigo till 15 years; she was at home working hard till 16 years. The catamenia occurred at 21 years and were regular till January, 1903. She was strong till 1385; when she severely scalded her left foot; pallor was first noticed in 1888. In 1890 she had a second attack of typhoid fever, mild, with good recovery. In 1895 she was for two months in the Homœopathic Hospital with anæmia and traumatic ulceration of both inner malleoli. In 1900 she was for six months in St. Arnaud Hospital with the same; her spleen was then found to be enlarged and she had ulcers which were considered to be probably specific and which healed under rest and specific treatment; arsenic did her general state little good; the ulcers had been discharging off and on ever since on any long standing. In April, 1901, she was for four months in Ward 11 of the Melbourne Hospital; her spleen was then down to the umbilicus and there was marked hæmic bruit. The blood contained per cubic millimetre $2,800,000$ to $3,130,000$ red cells with no marked changes in shape ; 5200 white cells; and hæmoglobin, 53 per cent. Three weeks later she was for nine months in Ward 4. Both she and her sister (Case 2) were then given mercury and large doses of iodide in view of a possible specific origin without any benefit. Iron had no effect, but arsenic in increasing doses, and hypodermic injections of sodium cacodylate in large doses were at first beneficial but without lasting effect ; attacks of splenic pain with pyrexia occurred; the patient was finally discharged on May 23rd, 1902, somewhat improved by hospital feeding and régime, but apparently little influenced by any drug. From June, 1902, to March, 1903, she was again in St. Arnaud Hospital. On admission into Ward 12 in May, 1903, she was markedly anæmic with an anxious chlorotic expression; she had pain. dull and paroxysmal, over the spleen, the liver, and the kidneys ; there was a hrmic bruit; the spleen extended down below the umbilicus and inwards to the middle line; the liver was slightly enlarged ; there were attacks of vomiting for eight or nine days, with bile and blood; there was a dull, livid, chronically congested area over each internal malleolus, necrosed to the bone and discharging. She gave a history of anorexia for six years, palpitations and chlorotic tinge for four years, and dyspncea for three years. She had had epistaxis twice, several feverish attacks with temperature up to $100^{\circ} \mathrm{F}$., and diarrhcea and dysuria at times. There was no purpura. She was fairly nourished and presented no signs of hereditary syphilis. Despite stimulating diet, bone marrow, adrenalin, arsenic, hæmatogen, and ferric chloride in large doses she gradually grew worse, periods of feeling well alternating with depression and malaise. I am indebted to our pathologist, Dr. Mollison, for the following and all other blood examinations made in the Melbourne Hospital :-

\begin{tabular}{|c|c|c|c|c|c|}
\hline \multicolumn{2}{|c|}{ Date. } & \multicolumn{3}{|c|}{ Red cells. } & White cells. \\
\hline April & 7 th, 1903 & .......... & $2,960,000$ & (.......... & No leucocytosi \\
\hline$"$ & 8th, , & (......... & $\begin{array}{l}\text { Slight } \\
\text { micro- } \\
\text { poikilo- }\end{array}$ & cytosis & 8000 \\
\hline$"$ & $\begin{array}{l}\text { 14th, ," } \\
\text { 23rd, ," }\end{array}$ & ? & $\begin{array}{l}3,500,000 \\
3,500,900\end{array}$ & …....... & 6000 \\
\hline
\end{tabular}

Pallor was slight and there was slight poikilocytosis; there was no polychromatophilia ; there was no marked micro- or megalo-cytosis; the white cells were chiefly polynuclear there were a few lymphocytes, but no myelocytes or baso-

Date. Red cells. White cells. Hæmoglobin. Colour July 14th, 1903 ... 3,200,000 ... About normal ... 55 per cent. ... 0.86

philes. The red corpuscles then fell to $2,780,000$ and the hæmoglobin to 50 per cent. She became weaker and generally worse and went home for a month. Returning on Sept. 3rd, under bone marrow, arsenic, ferric chloride, and thymus extract her red cells rose to $3,600,000$ and the hæmoglobin to 65 per cent., falling again on Oct. 15th-the red cells to $2,350,000$ and the hromoglobin to 70 per cent. On the 27th Lr. Stirling successfully removed the spleen though it was very adherent and the bowel became torn. On Nov. 2nd the blood count was: red cells 3,190,000 and hæmoglobin 60 per cent. On the 12 th the red cells were $4,600,000$. On the 24th she was out of ber. On the 26th the red cells were 4,480,000, with slight leucocy tosis, and the hæmoglobin was 70 per cent. On Dec. 3rd the red cells were 4,120,000 the white cells were 10,000 , and the hæmoglobin was 85 per cent. On the 16 th the red cells were $4,670,000$, the white cells were 18,000 , and the hrmoglobin was 85 per cent. On the 21st she was discharged, looking and feeling fairly well. On the 29 th the red cells were $4,480,000$, the white cells were 20,000 , and the hænoglobin was 85 per cent. She has continued ever since free from pain and from the symptoms of severe anæmia, but the malleolar ulcers again broke down and rapidly healed under bromine and rest. On May 19th the red cells were $4,310,000$, with some poikilocytosis, and the white cells were 20,000 , with an occasional myelocyte and mast cell

For the examination of the spleen I am indebted to Dr Constance Ellis. It weighed $43 \frac{3}{4}$ ounces after being in spirit, and cut with a much firmer section than an ordinary spleen. Microscopically the capsule was thickened but not in any remarkable degree. There were few nuclei in the capsule and those present were very much elongated. The spleen tissue just under the capsule was much compressed, there being hardly any blood spaces in it, while there was very much yellowish-brown pigment. 'The trabeculæ corresponding with the capsule were slightly increased in thickness but not markedly so; they also contained only a few elongated nuclei. Pigment was noticeably present in all parts of the section. The most marked characteristic was the great increase in the fibrillar framework of the spleen pulp, made up of the anastomosing processes of endothelial cells, with their rounded or elongated nuclei. While these cells were numerous, the lymphocytic cells of the spleen pulp were few in number, and this corresponded with another marked change-namely, the paucity of Malpighian bodies which were very few, both in absolute numbers and also in the number of cells they contained; their lymphoid tissue seemed to have been encroached upon by the endo. thelial framework the large clear cells of which were frequent both in the centres and through the periphery of the tufts. The Malpighian corpuscles gave the impression of having been encroached upon by the fibrosis of the surrounding pulp. The blood-vessels had thick walls, though it was in most instances the adventitia that was increased rather than the intima, though, in some cases, this also had encroached upon the lumen.

CASE 2.-The patient, who was a female, aged 19 years, came under notice on account of visiting her sister. She was admitted to the hospital on May 23rd, 1903. She was anæmic but not chlorotic, with splenic enlargement well marked, but much less than in the case of her sister. She had palpitations, which at times were violent, and vertigo, which at times prevented standing; she became tired on the least exertion. She had a hæmic bruit, splenic pain (which was often very severe and radiating to the axilla and the back), anorexia, frequent nausea, and some diarrhœa lately, but no vomiting or hæmorrhages. She had

\begin{tabular}{|c|c|c|c|}
\hline .......... & $\begin{array}{l}\text { Hæmoglobin. } \\
65 \text { per cent. }\end{array}$ & $\cdots$ & Colour index, $1 \cdot 14$ \\
\hline ............ & $\left\{\begin{array}{c}\text { Chiefly } \\
\text { polynuclear }\end{array}\right.$ & …...... & $\left.\begin{array}{l}\text { No marked micro- } \\
\text { megalo- }\end{array}\right\}$ cytosis. \\
\hline (n......... & $\begin{array}{l}75 \text { per cent. } \\
65 \stackrel{n}{ }\end{array}$ & (.......... & Colour index, 0.92 . \\
\hline
\end{tabular}

had three febrile attacks in the last two months. The urine had a specific gravity of 1009 and was neutral; it contained no albumin. She had always been slightly pale and had never been quite strong. She had suffered from conges. tion of the lungs at six years of age, from typhoid ferer at seven years, and for a few weeks from jaundice at eight years. The catamenia commenced at 14 years of age and had been regular but scanty. She had been in service since 13 years of age, in an easy place and good surroundings; she was under no treatment until the time she was in Ward 4 with her sister. She never had any cedema, chlorotic tinge, hæmorrhage, fever, or gastro-intestinal troubles. When in Ward 4 there were some poikilocytosis and normoblasts, but there was no leucocytosis. After her discharge she went back to serrice for 12 months but since became worse again. Neither she nor her sister has at present any Widal reaction. She was 
placed on similar treatment to her sister. The condition of the blood was as follows:-

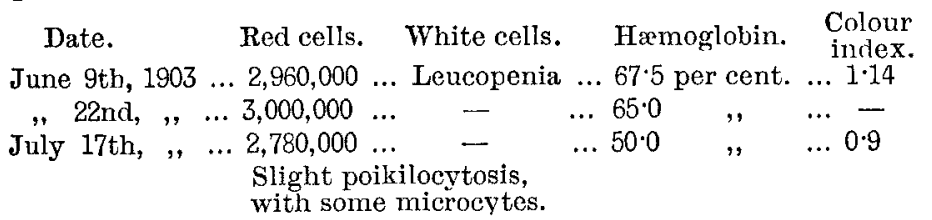

She was discharged on July 30th. She remained much the same and was readmitted on Dec. 24th with a view to operation. On Jan. 9th, 1904, her blood count was: red cells, 3,700,000; hæmoglobin, 95 per cent.; and white cells, fairly normal. On the 19th Dr. Stirling removed her spleen without any difficulty and she made a rapid recovery. On Feb. 3rd her blood count was: red cells, 4,120,000; white cells, 6000; and hæmoglobin, 80 per cent. On the 11 th the count was: red cells, 4,800,000; white cells, 8000 ; and hæmoglobin, 85 per cent. Since the splenectomy she has remained free from pain. Neither she nor her sister has shown any signs of lymphatic enlargement.

For the examination of her spleen I am indebted to Dr. R. J. Bull. It was uniformly enlarged, measuring 6 inches by 4 inches by $2 \frac{1}{4}$ inches and weighing $14 \frac{3}{4}$ ounces. The surface was smooth; the capsule was slightly thickened; there was no perisplenitis. The cut surface presented a fairly homogeneous appearance and the substance was firmer than normal. There were no lymphoid masses present.

The most noticeable feature on microscopic examination was a marked increase in the fibrillar reticulum of the splenic pulp, with diminution of the number of lymphocytes. The Malpighian follicles were fewer in number than normal and the supplying arteries were thick-walled with the lumen frequently obliterated. The large amount of coarsely grained blood pigment indicated considerable hæmolysis. The relatively few nuclei in the fibrous trabeculæ and bloodvessel walls, together with the swollen appearance of the fibrils in the framework generally and in the vessel walls, were suggestive of degeneration of a hyaline type rather than the result purely of a chronic inflammatory condition such as syphilis. Staining methods proved the absence of lardaceous change. The pathology, no less than the clinical history and blood pictures of the two cases, is thus in accordance with that of the condition known as splenic anæmia.

CASE 3.-The patient, who was a female, aged 23 years, was also found similarly affected. She appeared to have been quite strong up to her marriage which had taken place four years previously, except for three mild attacks of "typhoid fever" in 1884, 1890, and 1896. The first occurred at Portarlington with six others, the second at South Melbourne with several others, and in the last she alone of the family was affected. In the last two attacks she was in the Homcopathic Hospital and in all of them she made a good recovery. Her catamenia were delayed, however, until she was 18 years of age but she had always been regular. At 21 years of age she was jaundiced for a week. She was married at 19 years of age and had never been quite well since. She had twins within that year, both of whom died within a few weeks. In May, 1901, Dr. Gertrude Halley treated her for an ulcerated leg which healed under treatment. On June 21st, 1902, she was confined in the Women's Hospital of a healthy child, but remained therein for five weeks owing to sepsis after adherent placenta. No note occurs as to any anæmia or splenic enlargement. The child became weakly and several months later she herself was an out-patient at the Queen Victoria Hospital in May, 1902, when Dr. Halley reported that she looked very ill and that the ulcer had broken down again. No complaint was made of splenic pain and no examination was made. The baby died at five months from pneumonia. When examined by me last June the spleen reached below the umbilicus and within one inch of the middle line; her general health was unsatisfactory; she was two months pregnant; she was dyspnœic on exertion; she had palpitations and often vertigo on sitting up; she had been chlorotic in tinge since marriage and anæmic for 12 months; she had no hæmic bruit and no history of hæmorrhages or gastro-intestinal disturbances. She was again confined of twins in the Women's Hospital in February last. Dr. J. F. Harris, to whom I am indebted for the account of the patient when in the Women's Hospital, states that the twins were healthy, weighing five pounds each.
There was a large common placenta which was adberent and was removed manually, the spleen being felt from within. The placenta, though large and somewhat fibrous, could not be called typically specific. She again ran a septic course and was normal in ten dass; she was intensely anæmic and her resisting power against sepsis was exceptionally feeble. So far she has not permitted treatment or examination of the blood.

CASE 4.-The next stage in this interesting series was the discovery of two cases in a nephew and niece of the foregoing and a similar condition in the father of one of them, this latter being a male, aged 30 years. He was strong and well till he had an attack of typhoid fever at Portarlington in 1884, with six others of the family. It was a severe attack, with convalescence lasting three months. The man had been pale and slightly dyspnoic ever since. He had influenza ten years later and was thought to be tuberculous. He gave no hi tory of syncope, vertigo, hæmorrhage, pyrexial attacks, splenic pain, or gastro-intestinal troubles. He had the facies of his sisters; the spleen was notably enlarged. Dr. L. J. Balfour found his blood to contain 2,250,000 red cells and 9000 white cells per cubic millimetre; the hæmoglobin was 65 per cent. Of 66 white corpuscles counted there were 53 polynuclears, or 80 per cent. ten lymphocytes and mononuclears, or 15 per cent.; and three eosinophiles, or 4.5 per cent. While counting these leucocytes one normoblast was seen. The blood film did not show anything very marked. The chief alterations from the normal were found in the red cells and these alterations appeared in two ways-alterations in size and unequal staining. A few microcrtes were present which took the eosin stain more deeply than those of normal size. There was a much greater number, however, larger than the normal size, say varying from the normal (taken at $7 \cdot 5 \mu$ ) to about $10 \mu$. The larger forms showed a greater tendency towards the basic stain. Some of the red cells appeared nucleated. The film also showed an occasional normoblast. No basophilic granulations were noticed in the red cells, as were shown clearly in those of the patient's son (Case 5). No poikilocytosis was seen. The blood picture thus, like the others, corresponded very closely with that of splenic anæmia given by Da Costa in his " Hæmatology," p. 234.

(The three sisters and the brother were shown at a meeting of a medical society. The two from whom the spleens had been removed were in marked contrast with the other two, who looked pale, chlorotic, and anxious, just as their sister had appeared when present at the meeting 12 months before. The two spleens were also exhibited and Dr. Ellis and Dr. Bull showed sections under the microscope, illustrating their descriptions.)

CASES 5 and 6.-For the following account of the condition of the two children I am indebted to Dr. Summons of the Children's Hospital. The first patient, who was a male, seven years old, was admitted to hospital on May 14th, 1904. The child was taken to hospital because of paleness, headache, and attacks of vomiting. When examined he was fairly anæmic, had slight faucitis, vomited two or three times, and had a headache and temperature of $103^{\circ} \mathrm{F}$. The heart apex beat was in the fifth interspace in the nipple line. On auscultation a hæmic murmur was found to be present. The lungs were clear, the liver was slightly enlarged, and the spleen, two fingers' breadth below the costal margin and the notch, was easily palpable. There was no glandular enlargement anywhere. The febrile condition rapidly subsided and on the 16th the boy was well in himself. The mother stated that he not infrequently had similar attacks. The blood count made by Dr. Balfour, gave 3,600,000 red corpuscles and 14,100 white corpuscles per cubic millimetre and hæmoglobin 40 per cent. The blood smear showed nucleated red corpuscles fairly abundant. The red corpuscles were of various sizes, from well-stained microcytes to megalocytes. The staining of the red corpuscles was interesting. Many of them took up the basic part of the Jenner stain in various degrees as a diffuse blueness or as definite numerous granules. Some of the red corpuscles were vacuolated but the majority of them were normal. The white corpuscles stained well and showed all the usual types as polymorphonuclears, eosinophiles, basic, and lymphocytes ; these last were in excess. On the 28 th, with no recent felorile reaction, the hæmoglobin was 57 per cent.; there were $2,655,000$ red corpuscles and 11,200 white corpuscles per cubic millimetre. The blood smear was similar to the previous ones, except that the nucleated red corpuscles were less numerous. The 
boy's colour improved and he was discharged on June 5th, 1904, very much better. The second patient, who was a girl aged ten years, was admitted to hospital on May 24th, 1904, not because she was ill but for observation. She at times suffered from malaise. On examination the skin and mucous membranes were seen to be anæmic-looking. The lungs were clear. The heart apex beat was in the fifth interspace inside the nipple line. There was a systolic murmur very distinct in all areas but most marked at the base. The spleen was easily palpable, four fingers' breadth below the costal margin. The liver was not enlarged. 'The blood count showed $2,564,000$ red cells and 11,860 whire cells per cubic millimetre; the hæmoglobin was 55 per cent. The blood smear showed very little diffuse blue staining in the red corpuscles, which were markedly of different sizes, from the well-stained small microcyte to the large megalocyte. Numerous nucleated red blood corpuscles were present. The white corpuscles were of normal types and there was a definite increase in the percentage of lymphocytes. The child, while in hospital, had a severe heart failure and the mother informed us that she had a similar trouble last year. She is still in the hospital. In addition, Dr. Summons has kindly furnished me with an account of another case of splenic anæmia, making the third that has been treated in the Children's Hospital during the last 12 months. As it is apart from the foregoing series, it is subjoined to this paper as an addendum. I have to thank Dr. Balfour, Dr. Bull, Dr. Ellis, Dr. H. H. Fleming (St. Arnaud Hospital), Dr. Halley, Dr. Harris, Dr. Mollison, and Dr. Summons for their invaluable assistance in the directions already referred to.

Such is the strange series of cases which it has been my fortune to observe. It is full of matters of absorbing interest, such as the causation, the identity or otherwise of the conditions in the children and the adults, the occurrence of so many cases in one family, the possibility of its presence in others, the symptoms, conrse, and endings, the result of splenectomy, and the futility of other treatment. I can deal with these only very briefly.

In obscure causation, clinical history, blood picture, and pathology they are typical illustrations of splenic anæmia and their totality strongly supports the British and American view of considering that condition as a disease sui generis. As regards causation I remain entirely in the dark. There is no evidence of hereditary syphilis, rickets, or other known constitutional cause, nor can typhoid fever be accepted as a satisfactory explanation. The same applies to any other certain and sufficient exciting cause. As regards identity all the adult cases have the same clinical history and blood picture, though in varying degrees, and Dr. Balfour's examination of the blood from father and son ends with the statement that "the blood picture of the son is somewhat similar to that of the father, the only difference being that it shows more marked changes." In this category the future development of the infantile cases is a matter of peculiar interest. The different patients, again, have apparently been affected at different ages and one at least seems to date back only a few years. Locality and occupation, similarly, seem to have played no certain part in causation. The futility of the ordinary and even of several extraordinary methods of treating anæmia in such cases is also well evidenced. Again, there is the light that the two cases of splenectomy may and do throw upon the functions of that ill-understood organ-the spleen. Evidently it is not essential to life, to digestion, or to blood development, and some people even do better without it. All this, of course, has been already known but not so markedly exemplified locally and yet any attempt to remove the spleen in the other great blood disease attended with splenic enlargement - viz., splenic leukæmia-seems fraught with the utmost peril and is almost invariably fatal. Apparently this is not from any distinctively splenic function but from different vascular conditions. Finally, the future of the spleenless cases is a matter worthy of continued study. So far, there seems to have been no consecutive lymphatic enlargement and apart from the blood (and even there not distinctively) there has been no evidence of substitutional action on the part of the bone-marrow. The one patent fact is that the patients are both much better in every way without their -pleens than they were with them, though they are still vulnerable and not in a state of rude health, and that the proper treatment for such cases is not at present so much medical as surgical.
ADDENDUM.

The following is a further case reported by Dr. Summons from the Children's Hospital.

CASE 7.- This patient, who was a male, aged 14 years, came to the hospital on August 17th, 1903, complaining of weakness, feverish attacks, anorexia, and paleness. There was a history of a continual dull pain in the left side of the abdomen for the past four months. 14 days previously to admission the boy became ill with extreme weakness and pains in the hips and knees, having then had to take to bed. Seven days later he had a profuse epistaxis but not any bleeding from anywhere else; his eyesight was also somewhat dim for a few days. There was no history of a previous attack of scarlet fever. On examination the patient had a pasty, anæmic condition of the skin and mucous membranes, with some puffiness about the face. The lips were brown and dryish, the tongue was flabby and coated, the temperature was $103^{\circ} \mathrm{F}$., and the pulse-rate was 160 , regular, and of a collapsing character. The patient had also a harsh croupy cough. The lungs, however, were quite clear. The heart's apex beat was in the fifth interspace just inside the nipple line. The sounds were rapid and clear. The liver was slightly enlarged and the spleen was two fingers' breadth below the costal margin and easily palpable. No glands were enlarged in any region. The urinary system was normal. The right pupil was definitely larger than the left; both reacted to light and to accommodation. On examination the fundi oculorum showed numerous old and new hæmorrhages, both large and small. There was deafness in the right ear, no air conduction being present, but bone conduction was good. The blood count was $3,200,000$ red corpuscles and 9380 white corpuscles per cubic millimetre ; the hæmoglobin was 40 per cent. The smear showed the red corpuscles staining unevenly and of various sizes, from the small microcptes to the large megalocytes. There was slight irregularity in their form. No nucleated red corpuscles were present. The white cells were of the normal types and showed nothing abnormal. 'The febrile condition rapidly subsided with rest but to the end there were frequent turns of feverishness. As time went on the retinal hæmorrhages altered in shape and transparency and the colour changed to white in the process of fibrosis ; numerous small fresh hæmorrhages occurred. The cough, suggestive of enlarged bronchial glands, persisted but no physical signs developed in the chest. The boy was on some days very well and on others he suffered from gastrointestinal trouble, with vomiting, nausea, and abdominal distress. He gradually became worse and by Sept. 28th he had severe frontal headache and became difficult to rouse. On Oct. 2nd an internal strabismus had developed in the left eye. The right pupil was much larger than the left and the outline was irregular. He did not hear what was said to him and the right side of the frontal region was tender all over. There was tenderness over the calves and great sciatic nerves. The knee-jerks were active and ankleclonus was obtainable on both sides. The boy was semicomatose and quickly passed into complete coma, dying during the afternoon of Oct. 5 th.

The notes of the post-mortem examination, which was made on Oct. 6th, were as follows. The brain was anæmic no lesion being present. The heart valves were clear the left ventricle was hypertrophied. There was a patch of atheroma on the septal cusp of the mitral valve The lungs showed organised pleuritic exudation at the lef apex; no tuberculous disease was present. The heart and lungs weighed 38 ounces; the lungs weighed 20 ounces. The bronchial glands were slightly enlarged but not pressing on the bronchi. There were petechial hæmorrhages under the pleuræ and hæmorrhages under the periosteum of the frontal bone. The spleen weighed 11 ounces. The liver was very tough and weighed two and three-quarter pounds. The pancreas was pliant, tough, and large. Hæmorrhages old and small were seen in the retroperitoneal tissues. The kidneys were large; the capsule peeled easily; it was not tough; the weight of both kidneys was 10 ounces. There was much pigmentation of the omentum and mesentery, due to old small hæmorrhages. There was slight enlargement of the glands in the posterior triangles of the neck and in the axillæ.

Remarks by Dr. Stirling ON The Operations.

The possible indications for extirpation of the spleen are nine in number, as follows. 1. Cases of malarial spleen. 2 Splenic anæmia or splenic pseudo-leukæmia. Sippy reports seven cases with five recoveries. Osler has reported 15 
cases, one of which was operated on with a fatal result. Warren (Annals of Surgery, 1901) reports a successful case. 3. Splenic leukrmia. Splenectomy in this disease is almost invariably followed by a fatal result. Hagen reports 42 cases with four recoveries. Death is due to secondary hæmorrhage owing to the condition of the walls of the large vessels. 4. Banti's disease, or hypertrophy of the spleen with cirrhosis of the liver. Hagen gives 16 cases with three deaths. Banti describes three successful cases. 5. Wandering spleen. 6. Abscess of the spleen. 7. Rupture of the spleen. Berger tabulated 80 cases in which the spleen was removed for hæmorrhage; 35 recovered. 8. Sarcoma of the spleen. 9. Possibly hydatid of the spleen. The two cases in question come under the second heading in the list. In the first the spleen was markedly adherent, very large, and difficult to manipulate. In the second it was smaller and much less adherent. Vanverts, quoted by Bovée, found that in 39 cases of enlargement with marked adhesions 28 died, while in 35 without adhesions only two died.

CASE 1. - The operation in this case was performed on Oct. 27th, 1903. Under ether an incision ten inches long was made through the left rectus abdominis extending downwards some distance below the umbilicus. The structures were divided down to the peritoneum and on opening this the enlarged spleen came into view, the anterior border being fairly moveable but the posterior surface was fixed. The inner surface was examined and many adhesions were found around the hilum. On passing the hand between it and the diaphragm it was found markedly adherent and below firmly attached to the splenic flexure and descending colon. It was decided to attack it on the inner surface first so as to control the blood-supply. There were at ieast four large arteries and a large number of smaller ones requiring division but the real trouble lay in dealing with enormous veins. A clamp put on the uppermost one slipped and considerable disconcerting bleeding followed. Most of this, however, came from the distal end. Piece by piece, and working cautiously, the whole gastric surface was separated. No ligatures had been as yet applied, the bleeding being controlled by innumerable clamps. The posterior border was then divided. After dividing the lieno-renal livament an attempt was made to free the organ from above and from the colon. In this manœuvre a considerable rent was male in the colon, admitting four fingers. At this point-one and a half hours after beginning the operationthe anæ:theti-t, Dr. E. H. Embley, informed me that her condition was too hazardous, from the hæmorrhage and shock, for much further manipulation. It was impossible, however, to discontinue without removing the spleen and repairing the torn bowel. Two quarts of normal saline solution being injecter into a vein of the arm and a tenth of a grain of strychnine hypodermically she rallied somewhat. The few bands holding the spleen were divided and the organ was removed. After ligating the vessels securely with silk the bowel, which meantime had been securely clamped by the fingers of my assi-tant (Dr. Cumpston), was now thoroughly cleansed and 24 interrupted sutures of silk were passed through all its coats. A tube and gauze drain were placed in position over the injured bowel and the wound was sutured in the usual way. The weight of the tumour after removal was seven pounds. On leaving the table the patient was in a condition of profound shock and her pulse was hardly perceptible. The whole operation took two and a half hours. She improved steadily. The tube and ganze drain were removed on the fifth day, the bowel sutures holding splendidly. On Nov. 5th the sutures were removed. The blood count showed 4,600,000 red cells per cubic millimetre. On the 12th she had a rigor lasting half an hour and vonited several times. The temperature was $100.8^{\circ}$ and the pulse-rate was 108 . On the following day she complained of great pain on the right side of the abdomen, but there was no distension or rigidity or tenderness at the site of the pain. I was told now for the first time that one of the sponges used at the operation was mising ; and as it was supposed to have been used on that side of the abdomen and to be the possible cause of rather alarming symptoms-pain, fever, and vomiting-I reopened the abdumen in the right semilunar line and made a search for it. Nothing was found. The symptoms improved and gradually disappeared in eight days, and shortly afterwards she was iransferred to Dr. Springthorpe's care again.

CASE 2.-The operation was performed on Jan. 19th, 1904 The ahtomen was opened by an incision slightly to the left of the middle line, reaching from a little below the costal margin to the level of the umbilicus. The stomach, intestines, and the left lobe of the liver were packed off with flat sponges and an attempt was made to bring the spleen into the wound. This being unsuccessful, part of the gastro-splenic omentum was ligated and divided. The viscus was then turned over and the lieno-renal ligament severed. Copious hæmorrhage here suddenly ensued from rupture of several large veins. These were picked up with long pressure forceps and secured. The spleen was then brought out of the abdomen and the remainder of the gastro-splenic omentum was divided and ligatured. No adhesions were found. On Jan. 28th the sutures were removed. On Feb. 1st the blood count showed 4.120,000 erythrocytes and 10,000 leucocytes per cubic millimetre and the hæmoglobin was 80 per cent. On the 11th the erythrocytes were $4,820,000$ and the leucocytes were 8000 ; the hæmoglobin was 85 per cent.

Although I am well aware that the median incision has the stamp of authority in any complicated case-such as the first-an incision to the left of the median line allows, perhaps, of better handling the adhesions of a large tumour. It is well, too, I think, to begin below and work upwards, having, of course, packed off the intestines well to the right. I would not, if such a case came my way again, depart from the plan of using forcipressure to control the bleeding, as, when the spleen has been removed, it is quite easy to ligate the vessels with much greater security than when working in the cramped area occupied by a large and adherent tumour. The veins, in spite of every care, are easily torn in the manipulations and the clamps used must be such as are not likely easily to slip. Some recommend in this and similar operations to leave a large quantity of saline solution in the abdominal cavity when the abdomen is closed, so as to minimise shock; but I have long since discarded it except in cases of ectopic gestation and, of course, with the soiling of the wound area by the contents of the colon, such a procedure would only have distributed the colon bacilli-if any were left after thorough sponging.

\section{A CASE OF PNEUMOCOCCIC PY ÆMIA WITH RECOVERY.}

By A. T. DAVIES, M.D. Cantab., F.R.C.P. Lond.,

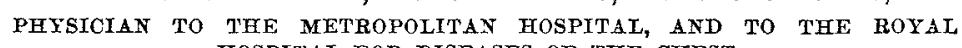
HOSPITAL FOR DISEASES OF THE CHEST;

\section{AND}

W. LANGDON BROWN, M.D. Cantab., M.R.C.P. Lond., SENIOR ASSISTANT PHYSICIAN TO THE METROPOLITAN HOSPITAL AND JUNIOR DEMONSTRATOR OF PRAC'TICAL MEDICINE, ST. BARTHOLOMEW'S HOSPITAI.

"PNeumonia is not a local but a universal disease; and the brunt of it may fall upon any part." 1 of the truth of this aphorism all are now convinced. The presence of pneumococci in the blood may be regarded as simply an integral part of the infective process. ${ }^{2}$ Since it is admitted that pneumonia is usually a septicæmia it is not surprising that it occasionally leads to a pyæmic state. The following case of pneumococcic infection resulting in bronchopneumonia, empyema, arthritis, and peritonitis, and ending. in recovery appears worthy of record in view of our recently extended knowledge on these points.

A litrle girl, aged eight years, was admitted to the Metropolitan Hospital on Dec. 6th, 1903, with the history of having been taken ill two days before admission. She was anæmic and looked ill and in pain. The respirations were very rapid (60), the pulse was quick (128), and the temperature rose to $102 \cdot 4^{\circ} \mathrm{F}$. soon after ad. mission. The left lung was dull to percussion in front and impaired behind; in front bronchial breathing and bronchophony and a few crepitations were heard. On the right side the note was dull at the base; bronchial breathing and crepitations were heard in patches. The heart was apparently normal. The abdomen was held rigidly and palpation over the right lumbar region was painful. The right knee-joint was swollen and tender. On the 8th the signs of consolidation on the right side extended all over the front. On the left side the signs were clearing up. The right knee appeared rather more inflamed. By the 11th the

\footnotetext{
1 Gee: Medical Lectures and Aphorisms, p. 251.
} 